\title{
EFEKTIVITAS PEMBELAJARAN KONTEKSTUAL DENGAN MENGGUNAKAN MEDIA AUDIOVISUAL DALAM MENINGKATKAN MOTIVASI DAN PRESTASI SISWA PADA PEMBELAJARAN IPS TERPADU
}

\author{
Martin Kahfi', Wawat Setiawati ${ }^{2}$, Yeli Ratnawati ${ }^{3}$, Asep Saepuloh ${ }^{4}$ \\ Magister Pendidikan Indonesia, Teknologi Pendidikan, Institut Pendidikan Indonesia
}

\begin{abstract}
Effective learning can be supported by a communication relationship between educators and students and a good learning environment. Based on the results of observations in schools, most of the student's learning achievement is still low, so it is necessary to apply a new innovation to optimize the learning process and outcomes. The purpose of this study was to determine the effectiveness of using contextual approaches assisted by audiovisual media in increasing student motivation and learning achievement in Integrated Social Science. The research design used a quasi-experimental design using a pretest-posttest control group design. The results showed that the learning achievement in the experimental class was higher with an average of 82 compared to the control class with an average of 65 , meaning that the use of a contextual approach assisted by audiovisual media was more effective than conventional methods in increasing student learning achievement in Integrated social science. A significant increase in student motivation between before and after learning using contextual learning assisted by audiovisual media.
\end{abstract}

Keywords: Contextual Approach, Learning Motivation, Learning Outcomes

Abstrak. Pembelajaran yang efektif dapat ditunjang dengan hubungan komunikasi antara pendidik dan peserta didik serta lingkungan belajar yang baik. Berdasarkan hasil pengamatan disekolah sebagian besar prestasi belajar siswa masih rendah maka perlu diterapkan suatu inovasi baru untuk mengoptimalkan proses dan hasil belajar. Tujuan penelitian ini adalah untuk mengetahui efektivitas penggunaan pendekatan kontekstual berbantuan media audiovisual dalam meningkatkan motivasi dan prestasi belajar siswa pada pembelajaran IPS Terpadu. Desain penelitian ini menggunakan metode Expermental quasy design menggunakan Pretest-Posttest Control Group Design. Hasil penelitian menunjukan prestasi belajar pada kelas eksperimen lebih tinggi yaitu dengan rata-rata 82 dibandingkan kelas kontrol dengan rata-rata 65 artinya penggunaan pendekatan kontekstual berbantuan media audiovisual lebih efektif dibandingkan metode konvensional dalam meningkatkan prestasi belajar peserta didik pada pembelajaran IPS Terpadu. Peningkatan motivasi belajar siswa yang signifikan antara sebelum dan sesudah pembelajaran dengan menggunakan pembelajaran kontekstual berbantuan media audiovisual.

\section{Kata Kunci: Pendekatan Kontekstual, Motivasi Belajar, Prestasi Belajar}

\section{LATAR BELAKANG}

Keberhasilan pembelajaran sangat dipengaruhi oleh guru dalam merancang pembelajaran dan mengimplemtasikan program pembelajaran dikelas. Teknologi pendidikan merupakan penggabungan antara teknologi pembelajaran, teknologi belajar, teknologi perkembangan, teknologi pengelolaan dan teknologi-teknologi lain untuk keperluan pemecahan masalah-masalah pendidikan. Sedangkan teknologi pembelajaran dikatakan sebagai penerapan secara sistematik dan sistematis dan tehnik-tehnik yang dirumuskan dari berbagai teori untuk keperluan pemecahan masalah-masalah pembelajaran.(Darmawan, 2012) Dalam pelaksanaan pembelajaran di kelas sarana atau media pembelajaran termasuk teknologi pembelajaran yang sangat membantu guru dalam mencapai tujuan-tujuan pembelajaran.

Peran seorang pendidik sebagai pengembang ilmu sangat besar untuk memilih dan melaksanakan pembelajaran yang efektif dan efisien bagi peserta didik. Pembelajaran yang baik dapat ditunjang dari suasana pembelajaran yang kondusif serta hubungan komunikasi antara pendidik, peserta didik dapat berjalan dengan baik. Proses pembelajaran akan efektif manakala memanfaatkan berbagai sarana dan prasarana yang tersedia termasuk memanfaatkan berbagai sumber belajar.

Peserta didik dalam melakukan aktivitas belajar memerlukan adanya pendorong atau motivasi tertentu agar proses belajarnya dapat 
mencapai prestasi belajar sesuai dengan tujuan yang diiinginkan. Motivasi merupakan aspek yang sangat dominan untuk membantu seseorang mencapai tujuannya. Tanpa adanya motivasi seorang peserta didik tidak mungkin memiliki kemauan untuk belajar.

Dalam rangka membangkitkan motivasi, seorang pendidik harus dapat menunjukkan pentingnya pengalaman dan materi belajar bagi kehidupan peserta didik dengan demikian peserta didik akan melakukan proses pembelajaran bukan hanya mengejar nilai semata apalagi hanya untuk mendapat pujian saja, tetapi mereka belajar dengan penuh kesadaran untuk memenuhi kebutuhannya(Astra et al., 2013).

Tinggi rendahnya motivasi peserta didik dipengaruhi oleh faktor-faktor dari peserta didik itu sendiri, baik dari faktor instrinsik maupun ekstrinsik.

Prestasi belajar berkaitan dengan pencapaian kompetensi sesuai dengan tujuan yang telah dirumuskan. Belajar ialah suatu usaha yang dilakukan seseorang untuk memperoleh suatu perubahan tingkah laku yang baru secara keseluruhan, sebagai hasil pengalamannya sendiri dalam interaksi dengan lingkungannya (Slameto.2010. Belajar Dan Faktor-Faktor Yang Mempengaruhi. Jakarta.Rhineka Cipta..Pdf, n.d.) Prestasi belajar bisa merupakan kompetensi yang dapat diukur yang berupa pengetahuan, sikap dan keterampilan sebagai interaksi aktif antara subyek belajar dengan obyek belajar selama berlangsungnya proses belajar mengajar untuk mencapai hasil belajar. Berdasarkan hasil observasi disekolah sebagian besar prestasi belajar siswa masih rendah, hal ini ditandai dengan rata-rata nilai hasil belajar IPS Terpadu yang belum mencapai KKM maka perlu diterapkan suatu inovasi baru untuk mengoptimalkan proses dan hasil belajar yaitu dengan menggunakan pendekatan kontekstual dengan media audio visual yang diharapkan dapat meningkatkan hasil belajar peserta didik. Tujuan penelitian ini adalah untuk mengetahui efektivitas penggunaan pendekatan kontekstual berbantuan media audiovisual dalam meningkatkan motivasi dan prestasi belajar siswa pada pembelajaran IPS Terpadu.

\section{RUMUSAN MASALAH}

Berdasarkan uraian latar belakang diatas, maka rumusan masalah dalam penilitian ini sebagai berikut;

1. Bagaimana efektifitas penggunaan pendekatan kontekstual berbantuan media audio visual dalam meningkatkan motivasi dan prestasi belajar siswa dibandingkan dengan metode konvesional pada pembelajaran IPS Terpadu?

2. Bagaimana tingkat efektivitas pelaksanaan pembelajaran kontekstual dalam meningkatkan motivasi siswa

\section{KAJIAN TEORITIS \\ Pembelajaran Kontekstual}

Pembelajaran kontekstual merupakan dalah satu pendekatan pembelajaran dengan mengaitkan antara materi yang diajarkannya dengan situasi dunia nyata siswa dan mendorong siswa membuat hubungan antara pengetahuan yang dimilikinya dengan penerapannya dalam kehidupannya. Senada dengan pernyataan menurut (Blanchard, A. (2001). Contextual Teaching and Learning. (Online).Pdf, n.d.) bahwa:

'Contextual teaching and learning is a conception of teaching and learning that helps teachers relate subject matter content to real world situations, and motivates students to make connections between knowledge and its applications to their lives as family members, citiezens, and workers and engage in the hard work that learning requires'.

Dalam pembelajaran dengan menggunakan pendekatan CTL guru harus menghindari mengajar sebagai proses penyampaian informasi, melainkan guru harus memandang siswa sebagai subjek belajar dengan segala keunikannya. Siswa adalah organisme yang aktif yang memiliki potensi untuk membangun pengetahuannya sendiri. (Chusni, 2016b) Ketika guru memberikan informasi kepada siswa, guru harus memberikan kesempatan kepada siswa untuk menggali informasi itu agar lebih bermakna bagi kehidupan mereka.

\section{Media Audiovisual}


Media dibagi dalam dua jenis yaitu 1) Audio visual diam yaitu media yang menampilkan suara dan gambar diam seperti film bingkai suara (sound slides), film rangkai suara, dan cetak suara 2) Audio visual gerak, yaitu media yang dapat menampilkan unsur suara dan gambar yang bergerak seperu film suara dan video cassette.(Syaiful Bahri Djamarah. 2006. Strategi Belajar Mengajar. Jakarta.Rineka Cipta.Pdf, n.d.) Media pembelajaran Audiovisual adalah media instruksional modern yang sesuai dengan perkembangan zaman (kemajuan ilmu pengetahuan dan tekhnologi), meliputi media yang dapat dilihat dan didengar.(Ghofur \& Youhanita, 2020)

Dalam pembelajaran dengan menggunakan media audio visual berfungsi sebagai media penyalur pesan dengan menyajikan unsur gambar dan suara sehingga materi yang disampaikan menjadi lebih konkret dan jelas. proses pembelajaran merupakan proses komunikasi dan berlangsung dalam suatu sistem, maka media pembelajaran memiliki posisi yang sangat penting dalam pembelajaran. Tanpa media, komunikasi tidak akan pernah terjadi dan proses pembelajaran sebagai proses komunikasi juga tidak akan dapat berlangsung secara optimal.

Media pembelajaran audiovisudal memiliki kelebihan dan kekurangan diantaranya dapat membantu menimbulkan pengertian dan ingatan yang kuat pada pesan yang disampaikan dan dapat dipadukan dengan unsur suara, merangsang minat dan perhatian siswa dengan gambar dan warna yang kongkrit dan aspek suara, progamnya mudah direvisi sesuai dengan kebutuhan dan penyimpanannya mudah karena ukurannya kecil, sedangkan kelemahannya antara lain memerlukan waktu yang relatif panjang untuk pembuatannya, serta memerlukan biaya yang relatif besar dan menyajikan gambar yang gerakannya terbatas.(Riyana, C. (2007). Media Pembelajaran. Bandung.CV. Wacana Prima..Pdf, n.d.)

\section{Motivasi Belajar}

Motivasi berasal dari kata motif yang dapat diartikan sebagai kekuatan yang terdapat pada dalam diri individu, yang menyebabkan individu tersebut bertindak atau berbuat.( $B$.
Uno, Hamzah. 2013. Teori Motivasi Dan Pengukurannya. Jakarta Bumi Aksara..Pdf, n.d.) Motivasi ditandai dengan munculnya perasaan dan afeksi seseorang, artinya motivasi relevan dengan persoalan-persoalan kejiwaan, afeksi, dan emosi yang dapat menentukan tingkah laku manusia.

Motivasi belajar merupakan kekuatan (power motivation), daya pendorong (driving force), atau alat pembangun kesediaan dan keinginan yang kuat dalam diri peserta didik untuk belajar secara aktif, kreatif, efektif, inovatif, dan menyenangkan dalam rangka perubahan perilaku, baik dalam aspek kognitif, afektif, maupun psikomotor. Motivasi belajar siswa menjadi faktor yang sangat penting guna memberikan respon yang baik terhadap pembelajaran dalam mencapai tujuan pembelajaran yang diharapkan. Motivasi belajar adalah dorongan internal dan eksternal pada siswa yang sedang belajar untuk mengadakan tingkah laku, pada umumnya dengan beberapa indikator atau unsur-unsur yang mendukung.(Nugroho, 2019) Motivasi belajar adalah keseluruhan daya penggerak psikis didalam siswa yang menimbulkan kegiatan belajar itu demi mencapai suatu tujuan.(Winkel.WS. 2005. Bimbingan Dan Konseling Di Institusi Pendidikan. Yogyakarta.Media Abadi., 2005) Ada empat fungsi motivasi belajar yaitu: 1) motivasi merupakan alat pendorong terjadinya prilaku belajar peserta didik; 2) motivasi merupakan alat untuk memengaruhi prestasi belajar peserta didik; 3) motivasi merupakan alat untuk memberikan direksi terhadap pencapaian tujuan pembelajaran.(Putri Ningrat et al., 2018)

\section{Hasil Belajar}

Proses pembelajaran merupakan proses yang dirancang sedemikian rupa oleh tenaga pendidik untuk membantu aktivitas belajar siswa dalam mencapai hasil belajar yang diharapkan. Hasil belajar sebagai salah satu indicator keberhasilan pelaksanaan pembelajaran yang telah dilakukan oleh tenaga pendidik. Apabila hasil belajar siswa dapat tercapai dengan baik maka dapat dikatakan proses pembelajaran efektif.

Hasil belajar adalah kemampuankemampuan yang dimiliki siswa setelah siswa 
menerima pengalaman belajarnya. Pengalaman belajar yang dimaksud adalah aktivitas yang dilakukan siswa untuk menguasai kompetensi tertentu yang telah ditetapkan oleh guru setelah selesai mengikuti pembelajaran. Menurut (Sistem et al., 2013) hasil belajar merupakan dampak dari segala proses memperoleh pengetahuan, hasil dari latihan, hasil dari proses perubahan tingkah laku yang dapat diukur baik melalui tes perilaku, tes kemampuan kognitif, maupun tes psikomotorik. Berdasarkan para ahli maka dapat disimpulkan bahwa hasil belajar merupakan kompetensi yang dimiliki oleh siswa yang mencakup kemampuan kognitif, afektif, dan psikomotorik setelah mengikuti pembelajaran yang diperoleh melalui pengukuran dan penilaian test hasil belajar yang dilakukan oleh guru.

\section{Prestasi Belajar}

Prestasi belajar adalah suatu bukti keberhasilan belajar atau kemampuan seorang siswa dalam melakukan kegiatan belajarnya sesuai dengan bobot yang dicapainya". (Abu Ahmadi Dan Widodo Supriyono. (1990). Psikologi Belajar Dan Mengajar. Bandung. Sinar Baru.Pdf, n.d.) Prestasi belajar merupakan hasil interaksi antara berbagai faktor yang mempengaruhinya baik dari dalam diri (faktor internal) maupun dari luar (faktor eksternal) individu.

Pengukuran prestasi belajar adalah sebuah proses berupa tindakan atau kegiatan untuk melihat sejauh mana tujuan-tujuan instruksional dapat dicapai oleh siswa dalam bentuk hasil belajar yang diperlihatkan setelah mereka menempuh proses belajar mengajar. Sama halnya dengan (Sugihartono, Dkk. (2007) Psikologi Pendidikan, Yogyakarta. UNY Press.Pdf, n.d.), mengungkapkan pengukuran prestasi belajar dimaksudkan untuk mengetahui seberapa jauh perubahan tingkah laku siswa setelah menghayati proses belajar. Sedangkan(Djaali \& Pudji Muljono. (2008). Pengukuran Dalam Bidang Pendidikan. Jakarta. $\quad P T$. Grasindo..Pdf, n.d.), mengungkapkan bahwa pengukuran prestasi belajar yaitu suatu kegiatan yang dilakukan untuk mengukur dalam arti memberi angka terhadap sesuatu yang disebut obyek pengukuran atau obyek ukur.

\section{METODE PENELITIAN}

Penelitian ini dirancang dengan desain penelitian Expermental quasy design. Desain penelitian Expermental quasy design yang digunakan adalah menggunakan Pretest-Posttest Control Group Design. Dalam desain ini terdapat dua kelompok yang dipilih secara random, kemudian diberi pretest untuk mengetahui keadaan awal adakah perbedaan antara kelompok eksperimen dan kelompok kontrol.

\section{HASIL PENELITIAN DAN PEMBAHASAN}

Penelitian dengan memberikan perlakuan kepada kedua kelas secara acak, dimana kelas $\mathrm{Va}$ sebagai kelas eksperimen menggunakan pembelajaran kontekstual berjumlah 36 dan kelas $\mathrm{Vb}$ sebagai kelas kontrol berjumlah 35 siswa menggunakan model pembelajaran konvensional. Berikut hasil nilai pretest dan posttest prestasi belajar siswa pada kelas eksperimen dan control;

\section{Tabel 1. Nilai Pretest dan Postest Kelompok Eksperimen dan Kontrol}

\begin{tabular}{|c|c|c|c|c|}
\cline { 2 - 5 } \multicolumn{1}{c|}{} & \multicolumn{2}{c|}{ Kelas Eksperimen } & \multicolumn{2}{c|}{ Kelas Kontrol } \\
\cline { 2 - 5 } \multicolumn{1}{c|}{} & Pretes & Postest & Pretes & Postest \\
\hline Rata-Rata & 19.8 & 82 & 18.8 & 65 \\
\hline Skor Maks & 27 & 90 & 26 & 75 \\
\hline Skor Min & 10 & 68 & 9 & 45 \\
\hline
\end{tabular}

Berdasarkan pada tabel 1 diperoleh data mengenai prestasi belajar pada kelas eksperimen menunjukan nilai rata-rata sebesar 82 lebih besar daripada kelas control sebesar 65 artinya penggunaan pendekatan kontekstual berbantuan media audiovisual lebih efektif dibandingkan metode konvensional dalam meningkatkan prestasi belajar peserta didik pada pembelajaran IPS Terpadu.

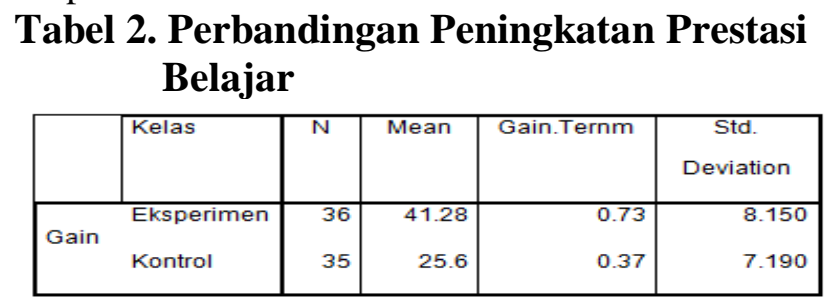

Data peningkatan prestasi belajar pada kelompok eksperimen sebesar 0.73 dengan kategori tinggi dan kelompok control sebesar 
0.37 dengan kategori rendah(Meltzer, D.E. The Relationship between Mathematics Preparation and Conceptual Learning Grains in Physics., n.d.). Selanjutnya mengenai peningkatan motivasi belajar siswa diperoleh $\mathrm{W}_{\text {hitung }}=401.5$, sedangkan $\mathrm{Z}_{\text {hitung }}=3.98$ dan $\mathrm{Z}_{\text {tabel }}=1,645$, dengan demikian $\mathrm{Z}_{\text {hitung }}>\mathrm{Z}_{\text {tabel }}$ maka $\mathrm{H}_{\mathrm{a}}$ diterima sehingga ada peningkatan motivasi belajar siswa yang signifikan antara sebelum dan sesudah pembelajaran dengan menggunakan pembelajaran kontekstual berbantuan media audiovisual pada pembelajaran IPS Terpadu.

Berdasarkan hasil penelitian diatas, penggunaan pendekatan kontekstual berbatuan media audiovisual lebih efektif meningkatkan prestasi belajar siswa dibandingkan dengan pembelajaran secara konvensional. Kelebihan pembelajaran kontekstual memuat 7 komponen utama konstruktivisme (contructivism), bertanya (questioning), menemukan (inquiry), masyarakat belajar (learning community), pemodelan (modelling), refleksi (reflection), dan penilaian sebenarnya (autentic Assessment)(Nurhadi. 2004. Pembelajaran Konstektual Dan Penerapannya Dalam KBK. Malang.UM Press..Pdf, n.d.). Senada dengan pembelajaran dengan pendekatan kontekstual yang telah dilaksanakan dalam penelitian ini, guru memberikan kesempatan kepada siswa untuk bertanya, membangun pengetahuannya, dan memberikan contoh ditunjang dengan penggunaan media audiovisual dalam penyampaian materi.

Media audiovisual menyajikan informasi yang lebih konkret sehingga memudahkan guru dalam menyampaikan materi dan peserta didik mudah dalam memahami materi pelajaran. Hal yang sama seperti hasil penelitian yang telah dilakukan oleh (Chusni, 2016a) menunjukan kenaikan yang tinggi dalam hasil belajar siswa dengan menggunakan pendekatan kontekstual.

\section{KESIMPULAN}

Penggunaan pendekatan kontekstual lebih efektif dibandingkan dengan metode konvensional dalam meningkatkan motivasi dan prestasi belajar siswa. Karakteristik peserta didik menjadi bagian yang perlu diperhatikan dalam merencanakan dan mengimpleme ntasikan pendekatan kontekstual dalam pembelajaran. Selain itu, penggunaan media pembelajaran perlu disesuaikan dengan karakteristik mata pelajaran maupun materi pelajaran.

\section{DAFTAR PUSTAKA}

Abu Ahmadi Dan Widodo Supriyono. (1990). Psikologi Belajar Dan Mengajar. Bandung. Sinar Baru.pdf. (n.d.).

Astra, G. N. W., Suarjana, I. M., \& Suwatra, I. I. W. (2013). Pengaruh model pembelajaran problem solving berbantuan media video pembelajaran matematika terhadap kemampuan pemecahan masalah siswa IV gugus IV kecamatan Sukasada. Jurnal Mimbar PGSD Universitas Pendidikan Ganesha, 1(1). https://ejournal.undiksha.ac.id/index.ph p/JJPGSD/article/view/1399/1260

B. Uno, Hamzah. 2013. Teori Motivasi dan Pengukurannya. Jakarta Bumi Aksara..pdf. (n.d.).

Blanchard, A. (2001). Contextual Teaching and Learning. (Online).pdf. (n.d.).

Chusni, M. M. (2016a). Penerapan Pendekatan Inkuiri Terbimbing Dengan Metode Pictorial Riddle Untuk Meningkatkan Pemahaman Konsep Fisika Siswa. Jurnal Pendidikan Fisika, 4(2), 111. https://doi.org/10.24127/jpf.v4i2.540

Chusni, M. M. (2016b). Penerapan pendekatan pembelajaran kontekstual untuk meningkatkan penguasaan konsep dasar listrik statis mahasiswa. Jurnal Riset Dan Kajian Pendidikan Fisika, $3(2)$, 45. https://doi.org/10.12928/jrkpf.v3i2.514 4

Darmawan, D. (2012). Pendidikan Teknologi Informasi dan Komunikasi.

Djaali \& Pudji Muljono. (2008). Pengukuran Dalam Bidang Pendidikan. Jakarta. PT. Grasindo..pdf. (n.d.).

Ghofur, A., \& Youhanita, E. (2020). Interactive Media Development to Improve Student Motivation. IJECA (International Journal of Education and Curriculum Application), 3(1), 1. 
terakreditasi Peringkat 4 (No. SK: 36/E/KPT/2019)

https://doi.org/10.31764/ijeca.v3i1.202

6

Meltzer, D.E. The Relationship between

Mathematics Preparation and

Conceptual Learning Grains in

Physics. (n.d.).

Nugroho, A. D. (2019). Interactive Multimedia and Mobile Application for Language Learning (Mall) Viewed From Motivation. JELLT (Journal of English Language and Language Teaching), 3(2), https://doi.org/10.36597/jellt.v3i2.5993

Nurhadi. 2004. Pembelajaran Konstektual dan Penerapannya dalam KBK. Malang.UM Press..pdf. (n.d.).

Putri Ningrat, S., Tegeh, I. M., \& Sumantri, M. (2018). Kontribusi Gaya Belajar Dan Motivasi Belajar Terhadap Hasil Belajar Bahasa Indonesia. Jurnal Ilmiah Sekolah Dasar, 2(3), 257. https://doi.org/10.23887/jisd.v2i3.1614 0

Riyana, C. (2007). Media Pembelajaran. Bandung.CV. Wacana Prima..pdf. (n.d.).

Sistem, M., Otomotif, K., \& Vokasi, P. (2013). Sukoco, K. S. Pengaruh Media Animasi Terhadap Hasil Belajar Dan Motivasi Belajar Siswa Materi Sistem Kelistrikan Otomotif. Pendidikan Vokasi, 2013. Vol. 3 , 1 -129. 3, 2013.

Slameto.2010. Belajar dan faktor-faktor yang Mempengaruhi. Jakarta.Rhineka Cipta..pdf. (n.d.).

Sugihartono, dkk. (2007) Psikologi Pendidikan, Yogyakarta. UNY Press.pdf. (n.d.).

Syaiful Bahri Djamarah. 2006. Strategi Belajar Mengajar. Jakarta.Rineka Cipta.pdf. (n.d.).

Winkel.WS. 2005. Bimbingan dan Konseling di Institusi Pendidikan. Yogyakarta.Media Abadi. (2005). 2005. 